\title{
From the organism of a body to the body of an organism: occurrence and meaning of the word 'organism' from the seventeenth to the nineteenth centuries
}

\author{
TOBIAS CHEUNG*
}

\begin{abstract}
This paper retraces the occurrence of the word 'organism' in writings of different authors from the seventeenth to the nineteenth centuries. It seeks to clarify chronological and conceptual shifts in the usage and meaning of the word. After earlier uses of the word in medieval sources, the Latin word organismus appeared in 1684 in Stahl's medicophysiological writings. Around 1700 it can be found in French (organisme), English (organism), Italian (organismo) and later also in German (Organismus). During the eighteenth century the word 'organism' generally referred to a specific principle or form of order that could be applied to plants, animals or the entire world. At the end of the eighteenth century the term became a generic name for individual living entities. From around 1830 the word 'organism' replaced the expressions 'organic' or 'organized body' as a recurrent technical term in the emerging biological disciplines.
\end{abstract}

There is still confusion in the secondary literature about the occurrence of the word 'organism' from the seventeenth to the nineteenth centuries. The first objective of this essay is to clarify the sources and contexts of its first usages; the second is to highlight a major shift in its meaning. At the end of the eighteenth century the 'organism'1 as a principle of order became a generic name for individuals as natural entities or living beings. The third aim is to investigate the establishment of the word 'organism' as a technical term in various research fields from around 1830. From a methodological point of view, the paper retraces the exact dates of the first appearances of a key term in the life sciences and of its usage in different discursive settings. As Reinhart Koselleck has pointed out, the discursive settings or semantic fields of a word can be used to distinguish different phases of the formation of disciplines. ${ }^{2}$ From a similar perspective,

\footnotetext{
* Kulturwissenschaftliches Seminar, Humboldt-Universität zu Berlin, Sophienstr. 22a, 10178 Berlin, Germany. Email: tobias.cheung@staff.hu-berlin.de.

I am grateful to Peter Baker, Hans-Jürgen Hess, Kai Torsten Kanz, Georg Töpfer, Martin Maurach, Max Pfister, Heinrich Schepers and Isolde Nortmeyer for their valuable hints and comments.

1 Quotation marks indicate words discussed in English and italics indicate the spelling of the word in the language in which it occurs in the original text. The word from the original text is sometimes given in parentheses after quotation marks. Capitalization reflects original usage. Unless otherwise indicated, translations are my own.
}

2 R. Koselleck, Vergangene Zukunft. Zur Semantik geschichtlicher Zeiten, 4th edn (1st edn 1989), Frankfurt am Main, 2000, 10-12. 
Georges Canguilhem and Rainer Specht focused on key terms in academic disciplines to reconstruct epistemological shifts. ${ }^{3}$

The different sections of the essay refer to those individual authors who used the word 'organism' and situate the word within a history of its occurrence and meaning. ${ }^{4}$ The first section briefly discusses two medieval sources to indicate the first occurrences of the word in European history while the second retraces the use of the word in the writings of John Evelyn and Nehemiah Grew. Around 1700 both used the word to refer to a principle or form of order. The third section explores the writings of Leibniz and Louis Bourguet, who also referred, though in different ways, to a form of order when they used the word 'organism'. In the fourth section the order of 'organism' and the order of 'mechanism' are discussed in the work of Georg Ernst Stahl. The fifth section highlights the shift of meaning of the word 'organism' as a form of order to a generic name of individuals that took place within German idealism at the end of the eighteenth century. The sixth section examines the micro-macrocosm problem in Naturphilosophien and physiological anthropologies. ${ }^{5}$ The final section begins around 1830 and focuses on various growing scientific fields, such as physiology and theories of the milieu, in which the word 'organism' became a recurrent technical term and replaced such compounds as 'organic body', 'living body' or 'organized body'. These compounds had prevailed since the sixteenth century in medical texts, natural history and anatomy. ${ }^{6}$

\section{Two medieval sources}

Before the second half of the seventeenth century, only two texts are known which use

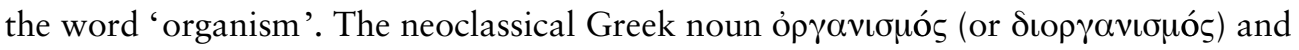

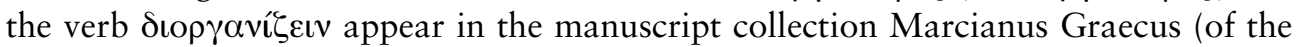
end of the tenth or the eleventh century). ${ }^{7}$ The text is undated and has no title. The

3 G. Canguilhem, 'La formation du concept de régulation biologique aux XVIIIe et XIXe siècles', in idem, Idéologie et rationalité dans l'histoire des sciences de la vie, Paris, 2000, 81-99; and R. Specht, 'Über "Occasio" und verwandte Begriffe bei Zabarella und Descartes', Archiv für Begriffsgeschichte (1972), 16, $1-27,12-13$.

4 Cf. C. Robin, 'Recherches historiques sur l'origine et le sens des termes organisme et organisation', Journal de l'anatomie et de physiologie normales et pathologiques de l'homme et des animaux (1880), 16, 1-55; H. Schmidt, Die lebendige Sprache. Zur Entstehung des Organismuskonzepts, Berlin, 1986 (Linguistische Studien. Reihe A. Arbeitsberichte 151); and O. Breidbach, 'Organismus', in Enzyklopädie Philosophie, (ed. H. J. Sandkühler et al.), 2 vols., Hamburg, 1999, i, 985-7. K. Kucharczik wrote his doctoral thesis ('Der Organismusbegriff in der Sprachwissenschaft des 19. Jahrhunderts, Technische Universität Berlin, 1998) on the usage of the word 'organism' in the linguistics of the nineteenth century.

5 In the late eighteenth century and the nineteenth, physiologies share research fields with medical studies, anatomies and so-called psychologies. They often focus, as physiological anthropologies, on the specific position of the human among other animals. Cf. F. Hildebrandt, Lehrbuch der Physiologie, 2nd edn, Erlangen, $1799,1-2$.

6 J. H. Wolf, Der Begriff»Organ« in der Medizin, München, 1971.

7 B. Balan, 'Premières recherches sur l'origine et la formation du concept de l'économie animale', Revue d'histoire des sciences (1975), 28, 289-326, 326 and footnote 127. For a verification and discussion of the source see M. Mertens, Les Alchimistes grecs. Zosime de Panoplis. Mémoires authentiques, Paris, 1995, Introduction, pp. xxii-xxix and liii-liv; and J. Letrouit, 'Chronologie des alchimistes grecs', in Alchimie: Art, 
unknown author discusses different alchemical techniques of distillation or 'sublimation' and refers to Zosimos, an important alchemist who lived at the end of the third or the beginning of the fourth century in the Egyptian town of Panopolis. ${ }^{8}$ The verb

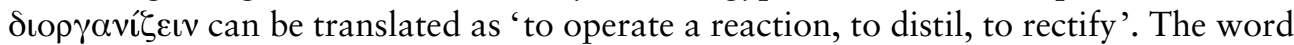

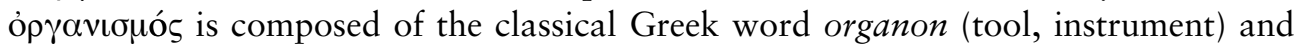

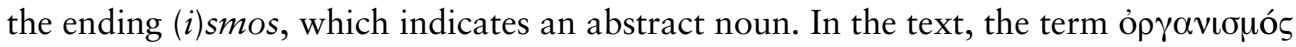
represents an apparatus in which liquids are distilled:

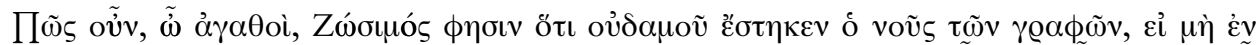

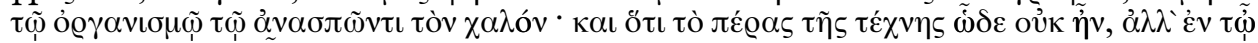

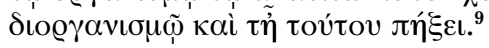

How can, ô philosophers, Zosimos say that the sense of the writings has been misunderstood, except that we can extract the copper in the apparatus (organism)? And how can he say that the proper end of these practices is not [the extraction], but the fixation [of the copper] in the apparatus?

Gerhoh of Reichersberg (1093-1169), provost of the same city and canon of Augsburg, is the author of the second medieval text, written between 1126 and 1132 . The text has the title De edificio Dei. The word 'organism' occurs only once and in the plural. In the text Gerhoh discusses the problem of the unity of the Roman church. He uses the word 'organism' for a (disharmonic) polyphony of human voices, to criticize metaphorically the reformation of the church, notably the worldly status of clerics:

Fuit enim ante aliquot annos ecclesia illa talibus clericis exposita, qui non canerent quasi ex uno ore, sed quasi ex ore diverso ac multum dissono; tum propter vocis inconcinnos organismos, theatralibus quibusdam modulis variatos; tum propter mores incompositos et magna discrepantia contra invicem divisos. ${ }^{10}$

Some years ago, the church [in Rome] fell into the hands of those clerics, who sang, so to speak, not with one mouth, but with many and differently sounding mouths because of the disharmonic polyphonies (organismos) of voices, varied through melodies that are used in the theatre, and of the practices that are confused and divided into great differences.

The noun organismus seems to be a nonce-word. Gerhoh did not use it in other writings. Blatt and Lefèvre quote the same passage without any other indication. ${ }^{11}$ The

histoire et mythes. Actes du 1er colloque international de la Société d'étude de l'histoire de l'alchemie (Paris, Collège de France, 14-15 mars 1991) (ed. D. Kahn and S. Matton), Paris and Milan, 1995, 11-93, 37 and 92.

8 The exact period of his life is unknown; see M. Mertens, op. cit. (7), p. xv.

9 Marcianus Graecus 299, M, f. 116v; in M. Berthelot, Collection des anciens alchimistes grecs, 3 vols., Osnabrück, 1967 (reprint; first published Paris, 1888), ii, 252. A French translation can be found in ibid., iii, 242. I am grateful to Robert Halleux and Diether R. Reinsch for their help with the translation.

10 Gerhoh of Reichersberg, De edificio Dei (1126-32), in Libelli de lite imperatorum et pontificum (ed. E. Dümmler et al.), 3 vols., 1891-7, iii, 172-3. Cf. Patrologia Latina, Vol. 194, col. 1258C. I have to thank Wolfgang Maaz and Marie-Luise Weber for their valuable hints and suggestions about the translation of the text, which has not been translated before. Weber also checked the spelling of the word organismos in the original manuscript in Munich and confirmed that the electronic resources of the new Mittellateinisches Wörterbuch (Bayerische Akademie der Wissenschaften) - which currently cover the period from 600 to 1280 within the borders of contemporary Germany - contain no other instances of the word.

11 F. Blatt und Y. Lefèvre, Novum glossarium mediae latinitatis ab anno DCCC usque ad annum MCC, Ordior-Oz, Hafniae, 1983, 776. No other instance of the word organismus in Latin dictionaries is known. Cf. Kucharczik, op. cit. (4), 23. 
noun is related to the Latin verb organizare, which already appears in the Vetus Latina (second to fourth centuries). It means 'to play an instrument' or 'to sing in more than one voice'. ${ }^{12}$ The verb has no equivalent in classical Greek. Until the seventeenth century no other occurrence of the word 'organism' is known.

\section{John Evelyn, Nehemiah Grew and the organism of a body}

In many etymological dictionaries and histories of science, John Evelyn's Sylva, first published in 1664, is given as containing the first usage of the word 'organism' in English. ${ }^{13}$ However, the word only occurs in a later edition of Evelyn's book. The full title of Evelyn's book was Sylva, Or a Discourse of Forest-Trees, and the Propagation of Timber in His Majesty's Dominions. It was published in February 1664 after the Commissioners of the Royal Navy initiated inquiries into the management of woodlands. ${ }^{14}$ In January 1660 Evelyn had already presented a paper on the anatomy of trees to the Royal Society and lectured on forest trees in October 1662. This latter lecture was printed as the first part of the book of $1664 .^{15}$ After Sylva the book contains two other texts, the Pomona, or an Appendix concerning Fruit-Trees, in relation to Cider, the Making and Several Ways of Ordering It and Kalendarium Hortense. The word 'organism' does not appear in Sylva, Pomona or Kalendarium hortense. Only in the enlarged fourth edition of $1706,{ }^{16}$ where Sylva is changed to Silva, did Evelyn use the word 'Organism' (in the plural) in the fourth book of Silva:

In a word, so astonishing and wonderful is the Organisms, Parts and Functions of Plants and Trees, that some have, as we said, attributed Animal Life to them, and that they were living creatures; for so did Anaxagoras, Empedocles, and even Plato himself. ${ }^{17}$

12 P. Stotz, Handbuch zur lateinischen Sprache des Mittelalters, 5 vols., München, 1996-2004, i (2002), 485 .

13 See, for example, R. K. Barnhart (ed.), The Barnhart Dictionary of Etymology, New York, 1988, 735; The Oxford English Dictionary (ed. J. Simpson and E. Weiner), 2nd edn, 20 vols., Oxford, 1989 (1st edn 1884-1928), x, 922; A. Dardi, Dalla provincia all'Europa: l'influsso del francese sull'italiano tra il 1650 e il 1715, Florence, 1992, 545, footnote 129; M. Echelard-Dumas, 'Der Begriff des Organismus bei Leibniz: “biologische Tatsache” und Fundierung' (tr. J. Orzschig), Studia Leibnitiana (1976), 8, 160-86, 160, footnote 1. Kucharczik (op. cit. (4), 22-3) refers also to Evelyn's Sylva for the first usage of the word 'organism' in the seventeenth century. The Oxford English Dictionary quotes a later edition of Evelyn's Sylva, but refers to the edition of 1664 for the first usage of the word.

14 Cf. G. de la Bédoyère, The Writings of John Evelyn, Woodbridge, 1995, 173-80.

15 C. R. Weld, A History of the Royal Society with Memoirs of the Presidents compiled from Authentic Documents, 2 vols., London, 1848, i, 101 and 137, footnote 15.

16 The fourth edition was divided into two parts. The first part contains 'Silva', and the second four other texts: 'Terra', 'Pomona', 'Acetaria' and 'Kalendarium hortense'.

17 J. Evelyn, Silva, Or a Discourse of Forest-Trees and the Propagation of Timber in His Majesty's Dominions ... In Two Books. Together with an Historical Account of the Sacredness and the Use of Standing Groves. Terra, A Philosophical Essay of Earth, being a Lecture in Course. To which is annexed Pomona: Or, An Appendix concenrning Fruit-Trees, in relation to Cyder; The Making, and several Ways of Ordering it. Published by Express Order of the Royal Society. Also Acetaria: Or, a Discourse of Sallets. With Kalendarium Hortense; Or The Gard'ners Almanack; Directing what he is to do Monthly throughout the Year, 4th edn, London, 1706 (1st edn 1664), 353. I also refer to a London, 1776 edition and a Brough, 2001 reprint of the 4 th edition. 
In the 1776 edition, edited and enlarged by Alexander Hunter after Evelyn's death, the same passage reads as follows:

In a word, so astonishing and wonderful is the organism, parts and functions of plants and trees, that some have, as we said, attributed animal life to them, and conceived that they were living creatures; for so did Anaxagoras, Empedocles, and even Plato himself. ${ }^{18}$

In both editions the passage is in Chapter XXXV, included in the fourth book of the first part, and entitled 'An Historical Account of the Sacrednesse, and Use of standing Groves, \&c'. The chapter had already been added to the second edition of 1670 , but without the section including the word 'Organism' in the fourth edition of 1706. The third edition of 1679 was a reprint of the 1670 edition. The 'Historical Account' of 1706 appears later on in various reprints and revised editions.

The word 'Organism' occurs only once in Evelyn's text. It points to a specific form of order 'which brings forth the lofty fir-tree, and the spreading oak ... without the least luxation, confusion or disorder of parts' ${ }^{19}$ For Evelyn, the development of trees relies on the 'perfect order' of an 'automat' that grows out of 'grains' or 'minute atoms' which contain not only 'the fœetus exquisitely formed' but also 'a second tree, ... and so on' ${ }^{20}$ Evelyn refers to theories of the preformation of organic order which were first formulated among microscopists such as Marcello Malphigi, Jan Swammerdam and William Croone. ${ }^{21}$

Five years before Evelyn, Nehemiah Grew had already used the capitalized word 'Organism' to indicate a form of order in his last book, the Cosmologia Sacra (1701). ${ }^{22}$ Like Evelyn, Grew was supported by the Royal Society; he had published the main results of his studies in botany and plant morphology in 1673 and $1687 .{ }^{23}$ The word 'Organism' is frequently used in the second book of the Cosmologia Sacra, in which Grew wanted to show that there is, besides the 'Corporeal world', 'a Vital world' of a

18 Evelyn, op. cit. (17), 1776 edn, 648.

19 Evelyn, op. cit. (17), 4th edn, 2001 reprint, 261.

20 Evelyn, op. cit. (17), 4th edn, 2001 reprint, 262-4. Cf. Evelyn, op. cit. (17), 4th edn, 2001 reprint, 262-3: 'Contemplate we again, what it is which begins the motion, and kindles the flame of these automata, causing them first to radiate in the earth, and then to display their top in the air'.

21 In 1671 Croone, a member of the Royal Society, produced a manuscript paper claiming that preformed embryonic structures can be detected in the unincubated chick embryo. In De la recherche de la vérité (1674) Nicolas Malebranche combined the concept of infinite divisibility of matter and preformation with a theory of insensible grains of trees that are encapsulated in each other.

22 For the contemporary religious and intellectual context of Grew's Cosmologia Sacra, and a brief summary of its content, see W. LeFanu, Nehemiah Grew: A Study and Bibliography of his Writings, Detroit, 1990, 53-5 and 143-6.

23 N. Grew, An Idea of a Phytological History Propounded. Together with a Continuation of the Anatomy of Vegetables, Particularly Prosecuted upon Roots. And an Account of the Vegetation of Roots. Grounded Chiefly thereupon, London, 1673; and N. Grew, The Anatomy of Plants, reprint, New York and London, 1965 (first published 1687). The seven chapters of The Anatomy of Plants are divided according to the 'Method of Nature her self, in her continued series of Vegetation; proceeding from the Seed sown, to the formation of the Root, Trunk, Branch, Leaf, Flower, Fruit, and last of all, of the Seed also to be sawn again; all which, we shall, in the same order, particularly speak of' (Grew, ibid., 1). For a discussion of Grew's methodology in The Anatomy of Plants see P. Anker, 'The economy of nature in the botany of Nehemiah Grew (1641-1712)', Archives of Natural History (2004), 31, 191-207. 
self-moving 'power' that 'regulates' movements in different ways. ${ }^{24}$ However, the 'Organism' appears to be just a kind of order of the 'Corporeal world'. It represents the 'Organizing of a Body':

the Corporeity of all Bodies, being the same; and Subtility, of all degrees, and in all Bodies, being Essentially the same thing: could any Body, by Subtility, become Vital; then any degree of Subtility, would produce some degree of Life ... Which is all Subtile Nonsense. Neither can Body be Vital, as it is Organized. For to the Organizing of a Body, these Three Things are required, and no more; viz. Bulk, Figure, and Mixture: Or, that the Parts of the Organ, be fitly Cized, Shaped, and set together. ${ }^{25}$

The order of 'organization' as a material, lifeless 'disposition' of parts in an organic body, that represents a necessary condition for the operations of its animating 'soul', was a frequent topos among such Cambridge Platonists as Henry More and Ralph Cudworth. The argument and the terminology (organizatio, dispositio, corpus organizato) can already be found in Francisco Suárez's De Anima. ${ }^{26}$

In Grew's Cosmologia the 'Organizing of a Body' appears ten sections later as the 'Organism of a body':

Wherefore, the Organism of a Body, although it hath nothing to do, in the production of Life, as hath been shewed: Yet is necessary, that every Body should have its Organism, agreeable to the Species of Life, in the Vital Principle, wherewith it is endowed. So as hereby to be fitted to receive from, and transfer unto Life, all manner of proper Motions and Impressions. ${ }^{27}$

The 'Organism' thus characterizes a specific corporeal order that is necessary for the 'co-operation' and 'mediation' between a 'vital principal' and the 'regularity' of a

24 N. Grew, Cosmologia Sacra: Or A DISCOURSE Of The UNIVERSE As it is the Creature and Kingdom OF GOD. Chiefly Written to Demonstrate the Truth and Excellency of the BIBLE; which contains the Laws of his Kingdom in this Lower World. In Five Books, London, 1701, Book I, 4-5 and 13-14. Garrett highlights the fact that Grew's late vitalism has been influenced by Henry More, Ralph Cudworth and John Ray: B. Garrett, 'Vitalism and teleology in the natural philosophy of Nehemiah Grew', BJHS (2003), 36, 63-81, 72.

25 Grew, op. cit. (24), Book II, Chapter 1 (12), 32-3. Cf. Grew, Anatomy of Plants, op. cit. (23), Dedication to King Charles II: 'That by all these Means, the Ascent of the Sap, the Distribution of Aer, the Confection of several sorts of liquors, as Lympha's, Milk, Oyls, Balsames; with other parts of Vegetation, are all contrived and brought about in a Mechanical way'.

26 The text was probably written between 1571 and 1574 and posthumously published in 1621 . Cf. Suárez, De Anima, Book III, Chapter II, n. 14; in Opera omnia, new edition (ed. Carlo Berton), 28 vols., Paris, $1856-78$, iii, 475b. For the use of the terms among medieval authors, especially within the context of late Aristotelian concepts of individualization, see D. Des Chene, Life's Form: Late Aristotelian Conceptions of the Soul, Ithaca and London, 2000, 94-102.

27 Grew, op. cit. (24), Book II, Chapter 1 (22), 34. He uses the word 'Organism' for the first time in Chapter 4 (Of Compounded Bodies, 4) of the first book (op. cit. (24), 18). For other references see Grew, op. cit. (24), Book II, Chapter 2 (11), 42: the 'advantageous Organism of the Eye' of birds for a 'Quicker Sight' and Book II, Chapter 3 (38), 46: 'But the Organism of every part of the Brain, particularly, of the Chambers of the Optics, Nerves, in which, if any where in the Brain, the Phantastick Images of Visible Things are made; is altogether different from that of the Eye.' Grew, op. cit. (24), Book I, Chapter 4 (7), 18, calls the 'Organism' also the 'natural Structure' of the organic body. Furthermore, Grew mentions once the 'Organism of Mind', op. cit. (24), Book II, Chapter 7 (51), 78, as a disposition of faculties for mental activities. 
body, in which the 'vital principle' directs and determines motions. Grew always refers to the 'Organism of a Body', and not, as later, in the nineteenth century, to the body of an organism. Furthermore, this 'Organism' is, as a 'natural structure' or pattern of various fibres, lifeless. However, to be 'organized' is not the only property of an 'Organ of Nature' in a living body. The 'Organism' of an 'Organ' never brings 'Life' into it:

The Variety of the Mixture, will not suffice to produce Life ... Unless the Parts of a Watch, set, as they ought to be, together; may be said to be more Vital, than when they lye in confused Heap ... And although we add the Auditory Nerves to the Ear, the Brain to the Nerves, and the Spirits to the Brain; yet is it still, but adding Body to Body, Art to Subtility, and Engine or Art to Art: Which, howsoever Curious, and Many; can never bring Life out of themselves, nor make one another to be Vital. ${ }^{28}$

Grew's notion of 'organism' came close to Leibniz's idea of a pre-existing 'organization' of organic parts. However, Leibniz developed a metaphysical system of monadic substances. For him, the active force and the body are substantially united in a single, individual monad, although they do not influence each other. For Grew, the active force and the body represent two distinct ontological regimes of the created world, although one regime (the active force) can influence the other through the 'organism' of a body.

\section{Leibniz, Louis Bourguet and the mécanisme organique}

Leibniz used the words organisme (only in singular and in French), organismus (in Latin) and organisation (in French) to characterize the divine mechanism of organic bodies. The word organisme appeared during his middle period, shortly after the publication of the Discourse de métaphysique (1686), in a letter to Antoine Arnauld of 9 September or 9 October $1687 .{ }^{29}$ This is currently the earliest known well-documented reference to the word 'organism' in his writings. Another reference to a text of 1686 in the Academy edition is dated post quem. ${ }^{30}$

Leibniz's letter to Arnauld has two versions. The first version reads as follows:

Enfin que les ceuvres de Dieu sont infiniment plus grandes, plus belles, plus nombreuses, et mieux ordonnées qu'on ne croit communement et que la machine ou l'organisme c'est à dire l'ordre leur est comme essentiel jusque dans les moindres parties. ${ }^{31}$

28 Grew, op. cit. (24), Book II, Chapter 1 (15), 22.

29 The word monade occurs around 1695 in Leibniz's texts. Cf. D. Rutherford, Leibniz and the Rational Order of Nature, Cambridge, 1995, 166.

30 G. W. Leibniz, Sämtliche Schriften und Briefe, Akademie-Ausgabe (ed. Deutschen Akademie der Wissenschaften), Berlin, 1923-, Section 6, Volume 4, Part B, 1615: 'Le rapport general et exacte de toutes choses entre elles, prouve que toutes les parties de la matiere sont pleines d'organisme. Car chaque partie de la matiere devant exprimer les autres et parmy les autres y ayant beaucoup d'organiques, il est manifest qu'il faut qu'il y ait de l'organique dans ce qui represente l'organique.' Nunziante gives this passage as the first use of the word organisme in Leibniz's writings. A.-M. Nunziante, Organismo come armonia: la genesi del concetto di organismo vivente in G. W. Leibniz, Trento, 2002, 121-2, footnote 25.

31 In R. Finster, Der Briefwechsel mit Antoine Arnauld, Hamburg, 1997, 308. This version was probably written earlier than the second version. Cf. ibid., 411 (notes). 
In the second version Leibniz replaces organisme with the word organisation:

Et surtout que les ouvrages de Dieu sont infiniment plus grandes, plus belles, plus nombreuses, et mieux ordonnés qu'on ne croit communement et que la machine ou l'organisation c'est à dire l'ordre, leur est comme essentiel jusque dans les moindres parties. ${ }^{32}$

Leibniz referred only once to the word organisme in his letters to Arnauld. He normally used various compounds such as 'organic body', 'living body' and 'organized body' in the plural and the singular. Some historians give a fragment of 1676 as the first use of the word organismus in Leibniz's writings. This fragment was published by Louis Couturat in G. W. Leibniz: Opuscules et fragments inédits (1903). ${ }^{33}$ Until now the text has been dated post quem to 1708 ; the date 1676 applies to the preceding fragment. ${ }^{34}$ After 1700 Leibniz more frequently used the French word organisme and sometimes also the Latin word organismus, as for example in the preface to the Théodicée (1710), in the Considérations sur les principes de la vie et sur les natures plastiques (1705) and in his correspondences with Lady Masham (1703-16), ${ }^{35}$ Des Bosses (1706-16) and Georg Ernst Stahl (1708-10). ${ }^{36}$

In Leibniz's writings the word organisation and the word organisme shared a common field of meaning. The organisme des animaux also represented for him the organisation des animaux. ${ }^{37}$ The organisme and the organisation (or organisation vitale $^{38}$ ) are principles of order that belong to the divine mechanism of nature. ${ }^{39}$ They are essential to matter because they result from compossible sets of primary possibilities that have been chosen by God according to the criterion of unity in diversity within the best of all possible worlds. ${ }^{40}$ The 'organism' is thus not a product of time or a generic name for individual living bodies. The parts of the world are 'full of an organism' (pleines d'organisme), ${ }^{41}$ and not of plural organisms.

32 Finster, op. cit. (31), 344.

33 In L. Couturat (ed.), Gottfried Wilhelm Leibniz-Opuscules et fragments inédits, Paris, 1903, Hildesheim, Zürich and New York, 1988, 11-16.

34 In Couturat, op. cit. (33), 10-11.

35 Lady Masham wrote in English but used the French word Organisme, with a capital. Compare C. I. Gerhardt, Die philosophischen Schriften von G. W. Leibniz, 7 vols., Hildesheim, 1978 (reprint; first published Berlin, 1875-1890), iii, 350 and 358.

36 See, for example, Leibniz, in Gerhardt, op. cit. (35), iii, 356, 361; vi, 41, 44, 544; vii, 418; and in Couturat, op. cit. (33), 16. In the Nouveaux essais Leibniz only used compounds such as corps organique or vivant organique. It seems that Leibniz did not use the word organisme in his correspondence with Louis Bourguet, but the correspondence has not yet been completely edited. Leibniz also referred to the first or second edition of Sylva in a comment on the Monita Sapientiae Christinae of Hostius (Cologne, 1630): 'Uti pro hortulanis Almanach Evelini, et Almanach oeconomicale in Colero'. Leibniz, op. cit. (30), Section 6, Volume 2, 150). The text is dated post quem October-November (?) 1671.

37 Cf. Leibniz, Préface, Théodicée (organisation), in Gerhardt, op. cit. (35), vi, 42; and letter to Clarke on 18 August 1716 (organisme), in ibid., vii, 418.

38 Leibniz, Nouveaux Essais II, 27, 6, in Gerhardt, op. cit. (35), v, 215.

39 Leibniz, in Couturat, op. cit. (33), 16: 'Natura enim cum a sapientissimo artifice fabricata sit, ubique in interioribus organica est. Et nibil aliud organismus viventium est quam divinior mechanismus in infinitum subtilitate procedens.'

40 Leibniz, letter to Arnauld on 9 September or 9 October 1687 (organisation), in Gerhardt, op. cit. (35), ii, 126; and letter to Lady Masham, 30 June 1704 (organisme), in ibid., iii, 356.

41 Leibniz, op. cit. (30), Section 6, Volume 4, Part B, 1615. 
Within the discourse of natural history, Louis Bourguet referred to Leibniz's notion of organic order as an 'organic mechanism' (mécanisme organique) of interrelated inner 'forms' (moules) in plants and animals. ${ }^{42}$ Bourguet discussed the organisation of these bodies in his Lettres philosophiques sur la formation des sels et des cristaux (1729). The development of germs of plants and animals depended for him on a specific primitive constitution or 'divine Predelineation' (Prédelineation divine) which he analysed in the third and fourth letters of the Lettres philosophiques. Bourguet used the word organisme to describe the 'systematic constitution' (constitution systématique) or 'composition' (composition) of the world, in which the 'particular systems' (systèmes particuliers) of plants and animals coexist. ${ }^{43}$ 'Corpuscles', which possess a 'vital activity', enter into their inner 'forms':

J'ai remarqué tantôt que tout étoit organique dans la Nature: Le Règne Minéral autant que le Végétal \& l'Animal, quoique dans un ordre fort différent de celui que les Philosophes \& les Chimistes ont imaginé. Cet organisme consiste en des Corpuscules d'une petitesse presqu'infinie, dont les figures sont géometriques, mais des plus simples ... Ces corpuscules doués chacun d'une activité vitale convenable à sa figure, entrent dans la composition de tous les Amas qu'il y a dans le Monde materiel. ${ }^{44}$

The word organisme occurs only once in the text. When Bourguet focused on concrete individuals, he always referred (as did Grew) to 'organized' or 'organic bodies' ${ }^{45}$ In the Dictionnaire général de la langue française du commencement du XVIIe siècle jusqu'à nos jours (1889-1901), Bourguet's Lettres philosophiques is cited as containing the first use of the word in the French context. ${ }^{46}$ Jean Le Clerc (1657-1735), who translated parts of Grew's Cosmologia sacra into French in the first two volumes of his Bibliothèque choisie (1703), used for the English term 'organism' the terms organization and disposition. ${ }^{47}$

In a letter from the philosopher and natural historian Antonio Schinella Conti to Antonio Vallisnieri in January 1726, Conti referred to Bourguet's Lettres philosophiques

42 Bourguet was in contact with Leibniz and Johann Christian Wolff. The Fonds Louis Bourguet of the Bibliothèque publique et universitaire in Neuchâtel also contains a Dissertation sur les monades and a Défense de la philosophie de Leibniz contre M. de Crousaz.

43 Cf. L. Bourguet, Lettres philosophiques sur la formation des sels et des crystaux et sur la génération et le méchanisme organique des Plantes et des Animaux, Amsterdam, 1729, Part 2, 8. For the notion of the échelle des êtres in Bourguet's writings see A. O. Lovejoy, The Great Chain of Being, Cambridge, MA and London, 1936; G. Barsanti, La Scala, la Mappa, l'Albero. Immagini e classificazioni della natura fra Sei e Ottocento, Florence, 1992; and A. Diekmann, Klassifikation-System->scala naturae. Das Ordnen der Objekte in Naturwissenschaft und Pharmazie zwischen 1700 und 1850, Stuttgart, 1992 (Quellen und Studien zur Geschichte der Pharmazie 64. Dissertation. Marburg 1992).

44 Bourguet, op. cit. (43), 66.

45 Bourguet was one of the first French naturalists to use often the word 'organized body' (corps organisé) instead of 'organic body'. For the influence of Bourguet's terminology on the French natural history see J. Schiller, 'La Notion d'organisation dans l'œuvre de Louis Bourguet (1678-1742)', Gesnerus (1975), 32, $87-97,93$.

46 A. Hatzfeld, A. Darmesteter and A. Thomas (eds.), Dictionnaire général de la langue française du commencement du XVIIe siècle jusqu'à nos jours ..., 7th edn, 2 vols., 1924 (1st edn 1889-1901), ii, 1640. The page reference of Bourguet's Lettres philosophiques in the article is not correct. Instead of page 66, the author of the article indicates page 6 (which was later copied in many other essays and books).

47 Cf. J. Le Clerc, Bibliothèque choisie, 28 vols., Amsterdam, 1703-18, ii (1703), 361 ('organization d'un corps' instead of 'Organism of a Body') and 377 ('disposition de l'Oeü̈l' instead of 'Organism of the Eye'). 
and his notion of an organismo del mondo. ${ }^{48} \mathrm{In}$ an earlier article in the journal La Gallerica di Minerva of 1708, 'organism' appeared as a specific form of order or an organismo mecanico that corresponded to the expressions of the soul of 'living bodies' (corpi viventi). ${ }^{49}$

Later on, Linnaeus used the Latin word organismus in his essay Oeconomia naturce (1750) to distinguish the 'preservation' (conservatio) of inorganic stones from the putrefaction and the development of corpora organica:

Quemamodum vita \& organismo destituuntur lapides, \& duriores sunt, nec putredini aut accrescentice obnoxii, sic etiam prae ceteris omnibus diutissime perdurant. ${ }^{50}$

Stones possess no life and organism, they are hard, and they are not affected by putrefaction or accretion. They thus last for the longest time among all other bodies.

Linnaeus used the word 'organism' in the singular. He referred not to individual organisms, but to a principle of order that is specific for organic bodies. ${ }^{51}$ As in William Harvey's theory of blood circulation, ${ }^{52}$ Linnaeus claimed that organic bodies are not just material aggregates, like stones, but bodies capable of a 'spontaneous propulsion' of liquids.

\section{The order of organism and the order of mechanism: Georg Ernst Stahl and the two orders of the living}

Georg Ernst Stahl, who between 1679 and 1683 studied medicine, anatomy and botany at the University of Jena, ${ }^{53}$ frequently used the Latin word organismus in some of his

48 Letter of Antonio Conti to Antonio Vallisnieri of 2 January 1726, in N. Badaloni, Antonio Conti. Scritti filosofico, Napoli, 1972, 402: 'non ho accusato la riccevuta della lettera unita alla disertazione della dama senese. Fattala trascrivere, io gliel'invierò insieme con la lettera del sig. Borghet. Il suo sistema dell'organismo del mondo contiene una bella idea, ma temo che l'ignoranza in cui siamo de'veri fenomeni e delle vere regole della natura non dia troppo del gusto del nostro secolo.' There are 180 letters from Antonio Vallisnieri to Bourguet (from 1710 to 1729 ) in the Fonds Louis Bourguet of the Bibliothèque publique et universitaire in Neuchâtel.

49 La Galleria di Minerva o vero notizie universali di quanto e stato scritto da Letterati d'Europa non solo nel presente Secolo, mà ancora ne' già trascorsi, in qualunque materia Sacra, e Profana, Retorica, Politica, Istorica, Cronologica, Geografica, Theologica, Filosofica, Matematica, Medica, Legale, e finalmente in ogui Scienza, e in ogni Arte sì Mecanica come Liberale, Venezia (1708), 6, 215: 'Nel organismo mecanico ò seconda lucubratione, dal principio tratta de spiriti degli animali, loco materia, generatione, virtù, e modo d'operare, secondo le loro figure, tutto sempre corrispondente a primi principii, poi passa all'Anima immortale ...' The author of the article resumes a work of Ferdinando Santanello (University of Naples). For more references on the occurence of the word organismo in the second half of the eighteenth century see Dardi, op. cit. (13); and Nuovo Cortelazzo: Dizionario etimologico della lingua italiana (ed. M. Cortelazzo and P. Zolli), 2nd edn, Bologna, 1999.

50 C. v. Linné, Oeconomia naturce, diss. [1749], resp. J. C. Biberg, 1750, 4.

51 In the German translation of 1777 (Des Ritter Carl von Linné auserlesene Abhandlungen aus der Naturgeschichte, Physick und Arzneywissenschaft, 3 vols., Leipzig, 1777, ii, 36), 'organismus' is translated with 'organs'.

52 W. Harvey, Exercitatio anatomica de motu cordis et sanguinis in animalibus, Frankfurt, 1628.

53 One of his teachers was the iatrochemist Georg Wolfgang Wedel. See B. J. Gottlieb, Bedeutung und Auswirkungen des hallischen Professors und kgl. Preuß. Leibarztes Georg Ernst Stahl auf den Vitalismus des XVIII. Jahrhunderts, insbesondere die Schule von Montpellier, Halle, 1943 (Nova Acta Leopoldina 12), 452-62; and J. Geyer-Kordesch, Pietismus, Medizin und Aufklärung in Preußen im 18. Jahrhundert. Das 
texts. ${ }^{54}$ It had already appeared in Stahl's 1684 doctoral thesis De Intestinis, eorumque Morbis ac Symptomatis, eognoscendis \& curandis. ${ }^{55}$ In this thesis Stahl distinguished between 'animated bodies' that have a regulating soul, the Dirigens microcosmicum, and 'aggregates' of a more or less confused order ${ }^{56}$ He referred in general to two different classes of animated bodies, the 'human bodies' and the 'animal bodies'.57 Stahl also distinguished between the material and the formal conception of organs. This distinction is analogous to the difference between 'concrete bodies' (corpora certa) and 'organic bodies or instruments' (corpora Organica, seu Instrumenta). ${ }^{58}$ The material conception of concrete bodies is mechanical and the formal conception of organic bodies is operational or instrumental. ${ }^{59}$ The latter explains the usage of parts and the purposefulness of the order of the whole body. Stahl called this order a 'formal organism' (organismus formalis). However, he used the word Organismus formalis solely for the title of a section in which he gave a detailed description of anatomical structures and physiological processes of various organs. ${ }^{60}$

In De motu tonico vitali (1692) and in De mechanismi et organismi diversitate (1706), Stahl often used the word Organismus (in the singular and with a capital) in opposition to a categorically different principle of order, the Mechanismus. As a general principle of order of organic or 'living bodies', the Organismus does not represent a generic name for the corpora viva.$^{61}$ However, the principle is proper to living bodies:

Quin à veritate alienissimum esset, principium vitale vocare: justam dispositionem partium corporis, tamquam elateriorum, filamentorum, funiculorum, catenularum, trabium, vectium, rotularum, cisternarum, antliarum, canalium, cataractarum, valvularum, cribrorum, und wer

Leben und Werk Georg Ernst Stahls, Tübingen, 2000 (Hallesche Beiträge zur europäischen Aufklärung 13), 16.

54 G. E. Stahl, De mechanismi et organismi diversitate (1706), in idem, Theoria medica vera. Physiologiam \& Pathologiam, tanquam doctrinae mediciae partes vere contemplativas, e naturae \& Artis veris fundamentis, intaminata ratione, $\mathcal{W}$ inconcussa experientia sistens, Halle, 1708, 6, 13, 16, 17, 18, 52. See also idem, Positiones, De Aestu Maris Microcosmici, Seu Fluxu et Refluxu Sanguinis: Tum in pluribus aliis luculentis Exemplis, tum praecipue Paroxysmo Febrili Tertianario, Manifesto in Sensus incurrente, mediante vero Motu Tonico Partium Porosarum, Ut praecipuo Organismo, in effectum deduci solito: Ad Motus Sanguinis Tonici veritatem ... usum, ulterius illustrandum, Febrium vero Pathologia Fundamentum, digito designandum, Halle, 1696.

55 The doctoral thesis is dated January 1684. The president of the jury was Rudolf Wilhelm Krauß (or Crause). Cf. G. E. Stahl, Dissertatio Medica Inauguralis De Intestinis, eorumque Morbis ac Symptomatis, eognoscendis \& curandis/Quam consensu et autoritate ... Praeside Dn. Rudolfo Wilhelmo Krauß ... Publicè stabilitum ibit Georgius Ernestus Stabl/Onoldo-Francus. Ad diem Januarii M DC XXCIV, Jena 1684 [54 pages, unnumbered], [9], title of Section I, Part 2: 'PHYSIOLOGICUM. De officio, \& sine organico Intestinorum, seu Organismi eorum Formali.' Later editions are from 1704 and 1711.

56 Stahl, op. cit. (55), [1].

57 In his French translation of Stahl's work, Blondin often used the word 'organism' for various other Latin terms (for example corpus organicus). Cf. T. Blondin, Euvres médico-philosophiques et pratiques de G.-E. Stahl. Traduites et commentées, 6 vols., Paris, 1859-63, iii, 11-12.

58 Stahl, op. cit. (55), [2].

59 Stahl, op. cit. (55), [11].

60 Stahl, op. cit. (55), [9-16].

61 Stahl, op. cit. (55), [1-3]. For the notion of life in Stahl's writings see F. P. de Ceglia, Introduzione alla fisiologia di Georg Ernst Stabl, Lecce, 2000, 33-40. 
weiß noch mehr; aut ex machiniis, pneumaticis, hydraulicis ... strictam applicationem ad corpus vivum formare. Sic enim confusio Mechanismi \& Organismi, in perpetuum succedet. ${ }^{2}$

It would be very strange to call the right disposition of the parts of the body, such as curves, filaments, tendons, joints, beams, handles, small wheels, wells, pumps, canals, cataracts, flaps, sieves, and who knows what, a vital principle. And it would also be strange to use only [the mechanism] of ... pneumatic or hydraulic machines to produce living bodies. This would result in an eternal confusion between mechanism and organism.

Stahl's notion of organismic order, in which the soul influences or informs the organic body, was criticized by Leibniz, for whom the soul and the body could only express themselves in a pre-established harmony as if they influenced each other. ${ }^{63}$ Unlike Stahl, Leibniz frequently used the word organisation and the compound corps organisé in the singular and the plural. ${ }^{64}$

Stahl's concept was also rejected by Christian Wolff, whose ontology dominated teaching at German universities in the first half of the eighteenth century. Wolff drew a sharp line between the ontology and the mechanical 'physiology' of organic bodies. ${ }^{65}$ He avoided the word 'organism' and used only compounds such as 'organic' or 'living body' ${ }^{66}$ It is not surprising therefore that the author of the entry 'Organismus' in the twenty-fifth volume of Zedler's dictionary (1740), whose main editor, Carl Günter Ludovici, supported the Wolffian school, ${ }^{67}$ referred to the mechanical order of the Organismus as an Organicum Mechanismum:

ORGANISMUS, ist nichts anders, als die Einrichtung der Theile eines organischen Cörpers. Er ist wenig oder gar nicht von dem Mechanismo unterschieden, vielweniger kan er, wie von einigen geschiehet, dem Mechanismo entgegen gesetzt werden. Will man unter beyden einen Unterscheid machen, so kan solcher in nichts anders bestehen, als daß der Mechanismus die Einrichtung der Theile aller und jeder Cörper; der Organismus aber die Theile nur organischer Cörper andeute ... Ja man könnte den Mechanismum eintheilen in Organicum Mechanismum und Non-Organicum Mechanismum, welches also zwey Arten des Mechanismi generalis wären. ${ }^{6}$

62 Stahl, Theoria medica vera, op. cit. (54), 29. Cf. Stahl, De mechanismi et organismi diversitate, op. cit. (54), 17.

63 F. Hartmann, 'Die LeIBNIZ-STAHL-Korrespondenz als Dialog zwischen monadischer und dualistisch"psycho-somatischer" Anthropologie', in Georg Ernst Stabl (1659-1734) in wissenschaftshistorischer Sicht. Leopoldina-Meeting am 29. und 30. Oktober 1998 in Halle (S.) (ed. D. von Engelhardt und A. Gierer), Halle (Saale), 2000, 97-124 (Acta Historica Leopoldina 30).

64 Leibniz, in Gerhardt, op. cit. (35), ii, 126; v, 214 and vi, 42. Duchesneau, Hartmann and Carvallo have discussed the differences between Leibniz's and Stahl's theories of organic order: F. Duchesneau, 'Leibniz and Stahl: divergences sur le concept d'organisme', Studia Leibnitiana (1995), 27, 185-212; Hartmann, op. cit. (63); and S. Carvallo, La controverse entre Stabl et Leibniz sur la vie, l'organisme et le mixte, Paris, 2004.

65 For Wolff's ontology and physiology see T. Cheung, 'Ontologie und Physiologie bei Christian Wolff (1679-1754)', Verhandlungen zur Geschichte und Theorie der Biologie (2004), 10, $263-81$.

66 C. J. Wolff, 'Von dem Begriff der Gesundheit (I)', in Gesammelte kleine philosophische Schriften welche besonders zu der Naturlehre und den damit verwandten Wissenschaften nehmlich der Meß- und Arzney-Kunst gehören ... (ed. J. Ecole), reprint, Hildesheim and New York, 1981 (first published Halle, 1736), 334-77, 349 (3, 'belebten Cörpers') and 355 (5, 'lebendiger Körper').

67 Ludovici, the main editor of Volumes 19-68, wrote a long article on Wolff's philosophy in the dictionary and also published a book with the title Ausfübrlicher Entwurf einer vollständigen Historie der Wolffischen Philosophie in three volumes (1737-8).

68 Grosses vollständiges Universal-Lexicon aller Wissenschafften und Künste, welche bishero durch menschlichen Verstand und Witz erfunden und verbessert worden (ed. J. A. Franckenstein, P. D. Longolius 
Basler cites this article as the first occurrence of the word Organismus in German. ${ }^{69}$ However, between Georges Buffon's Histoire naturelle générale et particulière (1749-89), Charles Bonnet's Considérations sur les corps organisés (1762) and Georges Cuvier's Leçons d'anatomie comparée (1800-5), the compounds corps organique, corps organisé and corps vivant were, in general, used solely to refer to individual living bodies. ${ }^{70}$ Only during the final decades of the eighteenth century did the reception of French histoire naturelle and the reaction to Kant's transcendental philosophy initiate discourses on the natural order of organized bodies in the German context. These initiatives resulted in a new terminology. ${ }^{71}$

\section{Individual organisms: the organismic turn in German idealism}

Around 1800 the word Organism can be found in the singular and the plural in Kant's later philosophy. Kant used the word not only for a principle of cosmological order, the 'total nexus' of mutual relations between all beings, but also for 'subjects'.72 'Subjects' exist as a part of the general 'organism' of nature, but represent also an individual Organism. ${ }^{73}$ This double occurrence of the word Organism both as a principle of order and as a generic name of individuals is characteristic of a shift in German idealism after Fichte's seminal lectures on the 'I' as an absolute subject. ${ }^{74}$ German philosophers tried to find a model in nature that corresponded to the idea of an absolute 'unconditioned' (unbedingt) unity of the 'I' and its capacity to experience the world. In the Erster Entwurf eines Systems der

and C. G. Ludovici), 69 vols., Halle and Leipzig, 1732-54, x, c. 1866. Adelung's Grammatisch-Kritisches Wörterbuch of 1777, however, only carried a short article about the word 'Organ', and no entry for the word 'organism'.

69 Deutsches Fremdwörterbuch (ed. O. Basler), 7 vols., Berlin, 1913-88, ii, 267.

70 Magdeleine de Saint-Agy employs the word organisme in the last volume (1845) of the Histoire des sciences naturelles. Cf. G. Cuvier and M. de Saint-Agy, Histoire des sciences naturelles, depuis leur origine jusqu'à nos jours, chez tous les peuples connus, 5 vols., Paris, 1841-5, v (1845), 313-435. Only the second and a part of the third volume relied on Cuvier's lectures on the history of science at the Collège de France. Cf. Cuvier and Saint-Agy, ibid., 434.

71 For the influence of Stahl's theory on such German naturalists and philosophers as Johann Christian Reill and Schelling see B. Gottlieb, op. cit. (53), 488-502.

72 For a discussion of the notion of organismic order in Kant's posthumous writings see C. Debru, 'L'Introduction du concept d'organisme dans la philosophie kantienne: 1790-1803', Archives de Philosophie (1980), 43, 487-514; R. Löw, Philosophie des Lebendigen - Der Begriff des Organischen bei Kant, sein Grund und seine Aktualität, Frankfurt am Main, 1980, 272; K. Düsing, Die Teleologie in Kants Weltbegriff, 2nd edn, Bonn, 1986 (1st edn 1968), 164 ff.; D. Outram, 'Uncertain legislator: Cuvier's laws of nature', Journal of the History of Biology (1986), 19, 323-68; and V. Mathieu, Kants Opus postumum (ed. G. Held), Frankfurt am Main, 1989, 226 and 235-8.

73 I. Kant, Akademie-Ausgabe. Kant's gesammelte Schriften (ed. Königlich Preußischen Akademie der Wissenschaften), Berlin and Leipzig, 1902-, xxi, 187 and xxii, 78. Kant normally used compounds such as organische Körper (cf. Critique of Judgment, 65, 73, 75, 80, 81, 82), organisierte Körper (cf. Critique of Judgment, 8), organisierte Produkte (cf. Critique of Judgment, 65, 67, 75), organisierte Geschöpfe (cf. Critique of Judgment, 64), organisierte Naturdinge (cf. Critique of Judgment, 82) and organische Naturwesen (cf. Critique of Judgment, 78).

74 J. G. Fichte, 'Grundlage der gesammten Wissenschaftslehre als Handschrift für seine Zuhörer' [1794], in idem, Fichtes Werke (ed. H. Fichte), 11 vols., Berlin, 1971, i, 83-328. 
Naturphilosophie, a sketch for lectures of 1799, Schelling referred to the mediating 'process' between the 'I' and the world (or the 'Non-I') as an 'assimilation' of the 'Non-I' into the 'I':

To save the unchangeable identity of your I, you must by necessity elevate the Non-I, of which plurality is the original form, to identity and assimilate it, so to speak, to the $\mathrm{I}^{75}$

The word 'assimilation' had already been used in medieval species-theories of per-

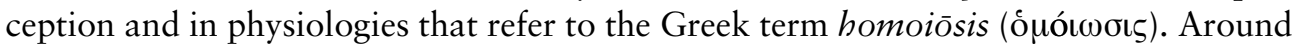
1750 it became a well-established expression among natural historians such as Buffon and Bonnet. ${ }^{76}$

Bonnet's model of 'preformed germs' described a process through which an organized unity differentiates and develops into multiple but interrelated structures that have a systematic relationship with the surrounding world. ${ }^{77}$ Schelling called the 'product' of such a continuous self-differentiating process an individuellen Organismus. ${ }^{78}$ In his Naturphilosophie Schelling also focused on the 'general organism of nature' (allgemeiner Organismus der Natur) and the recurrence in the microcosm of the 'individual organism' ${ }^{79}$ As in Kant's posthumously published writings and Bonnet's theory of organized bodies, the individual 'organism' represented for Schelling a particular system within the systemic and organic macrocosm of nature; such a conception, informed by Neoplatonic and alchemic thoughts, had already played an important role in the writings of Paracelsus, Boehme, More and Cudworth, and in the mystic visions of the Freemasons. ${ }^{80}$ Thus, by the end of the eighteenth century, many German philosophers, writers and naturalists (such as Herder, Hamann, Goethe, Schiller, Hegel, Novalis, Oken, Alexander von

75 F. W. J. Schelling, Erster Entwurf eines Systems der Naturphilosophie (1799), in idem, Sämmtliche Werke (ed. K. F. A. Schelling), 14 vols., Stuttgart and Augsburg, 1856-61, Section I, i, 193-4. For the notion of process in Schelling's natural philosophy see O. Breidbach, 'Prozessualität als systematische Kategorie in der Naturphilosophie Schellings', in Una Mirada a la filosofía de Schelling (ed. A. L. Coello), Vigo, 1999, 147-60.

76 For the use of the Greek term cf. Aristoteles' species-theory in De Anima, 429a, 17-18, and Galen's model of organic assimilation in De usu partium, Book I, Chapters 8 and 11. English physiologists and anatomists also used the term. Cf. Grew, Anatomy of Plants, op. cit. (23), 3; and Evelyn, op. cit. (17), 4th edn, 2001 reprint, 263. For the French context see H.-J. Rheinberger, 'Aspekte des Bedeutungswandels im Begriff organismischer Ähnlichkeit vom 18. zum 19. Jahrhundert', History and Philosophy of the Life Sciences (1986), 8, 237-50.

77 T. Cheung, 'Charles Bonnets allgemeine Systemtheorie organismischer Ordnung', History and Philosophy of the Life Sciences (2004), 26, 177-207.

78 Schelling, op. cit. (75), Section I, iii, 19.

79 Schelling, System der gesamten Philosophie (1804), in idem, Sämmtliche Werke (ed. K. F. A. Schelling), 14 vols., Stuttgart and Augsburg, 1856-61, Section I, vi, 301. See also Schelling, Von der Weltseele. Eine Hypothese der Höhern Physik zur Erklärung des allgemeinen Organismus (1798), in ibid., iii.

80 H. Böhme, Natur und Subjekt, Frankfurt am Main, 1988, 55-64 and 192-8. Stahl referred to the microcosm-macrocosm relation at the start of his doctoral thesis of 1684: Stahl, op. cit. (55), [1]. For the influence of Paracelsus and van Helmont on Stahl's notion of living bodies see J. Pagel, Einführung in die Geschichte der Medizin: fünfundzwanzig akademische Vorlesungen, 2nd edn, Berlin, 1915 (1st edn 1898), 301; and Gottlieb, op. cit. (53), 32. Grew also had contacts with iatrochemists. From 1663 to 1671 he studied medicine and natural philosophy at the University of Leiden, where one of his teachers was the Paracelsian chemist Franciscus de le Boë. See M. Hunter, Establishung the New Science: The Experience of the Early Royal Society, Woodbridge, 1989, 275; and LeFanu, op. cit. (22), 2-3. 
Humboldt, ${ }^{81}$ Carus and Ritter) were discussing the microcosm-macrocosm relationship. ${ }^{82}$ They all used the word Organismus in this context. ${ }^{83}$

\section{De toto in entibus: the micro-macrocosm problem in Naturphilosophien and physiological anthropologies}

In his Lebrbuch der Naturphilosophie (1808-11), Lorenz Oken defined 'organisms' as entities in which the whole is represented in its parts and the part transforms into the whole. Oken called these parts 'cells' or 'vesicles' (Bläschen). ${ }^{84}$ The Organismus is a self-differentiating system of 'cells':

Ein individualer, totaler, in sich geschlossener, durch sich selbst erregter und bewegter Körper, beißt Organismus ... ${ }^{85}$

In Oken's cosmology, individual 'organisms' were also parts of the all-embracing 'organism' of nature, itself characterized as a continuous alchemical process of the analysis and synthesis of elements (earth, water and air) according to specific principles of interaction (magnetism, chemical laws and galvanism). ${ }^{86}$ As in other Romantic

81 Humboldt used the word 'organism' in Ideen zu einer Physiognomik der Gewächse, Tübingen, 1807, 18, a lecture that was given in 1805 in Berlin. The word does not occur in Agustin-Pyrame de Candolle's writings.

82 In the Ideen zur Philosophie der Geschichte der Menschbeit, Herder used the expression Organismus der Natur to explain the 'uniformity' (Gleichförmigkeit) of the inner order of living bodies and the outer order of nature: 'der gleichförmige Organismus der Natur von Innen und Außen, wenn man ihn recht bestimmt, bleibt in allen Bildungen des Lebendigen unverkennbar'. J. G. Herder, Sämmtliche Werke (ed. B. Suphan), 33 vols., Berlin, 1877-1913, xiii, 116. See also G. W. F. Hegel, Jenaer kritische Schriften (1801), in idem, Hauptwerke in sechs Bänden, 6 vols., Darmstadt, 1999, i, 407; and idem, Phänomenologie des Geistes (1807), in ibid., i, 155. Ludwig Börne (1808) compares the human 'organism' with the 'organism' of a state: 'Man kann sich daher den menschlichen sowie jeden andern Organismus als einen Staat vorstellen, worin zwar sämtliche verschiedene Glieder einer gemeinschaftlichen Lebensregel unterworfen sind, wo aber jedes für sich wieder seine eigentümlichen Gesetze hat, die es befolgt'. Cf. L. Börne, 'Von dem Gelde' (1808), in idem, Sämtliche Werke (ed. I. and P. Rippmann), 5 vols., Düsseldorf, 1964-8, i, 74. The word Organismus appears further in many other German texts of this period, for example in the writings of Friedrich Matthison (1795), Christoph Wilhelm Hufeland (1797) and Adolph Eschenmayer (1799). For exact references see Deutsches Wörterbuch (ed. J. Grimm and W. Grimm), 33 vols., Leipzig, 1854-1971, vii, c. 1339-40; and Deutsches Fremdwörterbuch, op. cit. (69), ii, 267.

83 After Johann Georg Hamann and Johann Wilhelm Ritter had referred to the notion of 'living language' (lebende Sprache), Wilhelm von Humboldt frequently used the expression Organismus der Sprache. See J. G. Hamann, 'Beylage zum 37sten Stück der Königsbergschen gelehrten und politischen Zeitung' [1772], in idem, Sämtliche Werke (ed. J. Nadler), 6 vols., Vienna, 1957, iii, 22; J. W. Ritter, Fragmente aus dem Nachlasse eines jungen Physikers. Ein Taschenbuch für Freunde der Natur, Hanau/Main, 1984 (reprint; first published 1810), 270-7; and W. v. Humboldt, 'Ueber das vergleichende Sprachstudium in Beziehung auf die verschiedenen Epochen der Sprachentwicklung' [1820], in Wilhelm von Humboldt. Über die Sprache (ed. J. Trabant), Tübingen and Basel, 1994, 16-17.

84 L. Oken, Die Zeugung, Bamberg and Würzburg, 1805.

85 L. Oken, Lehrbuch der Naturphilosophie, 3 vols., Jena, 1809-11, ii (1810), Section 817, 10. Cf. ibid., Section 831, 12: 'Ein Organismus ist ein Individuum.' Oken had already used the word Organismus in 1802 (Grundriss der Naturphilosophie der Theorie der Sinne, mit der darauf gegründeten Classification der Thiere) and 1805 (Abriss des Systems der Biologie. Zum Behufe seiner Vorlesungen).

86 Oken, op. cit. (85), ii, Section 817, 5-9. 
concepts of nature, ${ }^{87}$ Oken held that each 'organism' individually repeated the order of the living world. The 'recapitulation' of the whole in the parts is most explicit in the embryonic development of higher 'organisms'. They transform from one lower organizational form into another until they reach their 'grade of perfection'.

Goethe, like Oken, focused on processes of individualization through the repetition and 'metamorphosis' of parts (leaves or vertebrates) that potentially represent the Organismus as an integrating whole. ${ }^{88}$ However, Goethe rarely used the word 'organism' ${ }^{89}$ In his essay Grundzüge der allgemeinen Naturbetrachtung (1832), Carl Gustave Carus combined Goethe's notion of metamorphosis with the order of micro-macrocosm:

Jedes lebendige Wesen, inwiefern es aus sich selbst Mittel seiner verschiedenen auszuübenden Wirkungen, d.i. Werkzenge, Organe, erschafft, heißt Organismus. - Die Natur, inwiefern sie rastlos neue Erscheinungen ibres inneren Lebens hervorruft, ist der Organismus schlechthin (Makrokosmos). Jedes einzelne aus sich selbst entwickelnde Naturwesen, inwiefern es nur im allgemeinen Organismus der Natur bestehen kann, ... heißt Theil-Organismus, (endlichindividueller Organismus, Mikrokosmos), und seine Entfaltung ist nur unter Einwirkung des allgemeinen Naturlebens möglich. ${ }^{90}$

In his Lehrbuch der Physiologie des Menschen (1809), Friedrich Ludwig Augustin, professor of pharmacology at the Collegio medico-chirurgico in Berlin, defined the 'organism' as a micro-macrocosmic monadic unity:

Jeder Organismus ... hat das Eigenthümliche, dass in ihm die vollkommenste Einigung der Vielheit in Einheit statt findet, d.i. dass das Besondere dem Ganzen vollkommen gleich ist, so dass das Ganze in dem Besonderen lebt, aber auch wieder ein Einzelnes und in seiner Art vom Ganzen verschieden, dass jedes Glied im Organismus in der Totalität und in der Einheit lebt, jedes Organ als ein Ganzes für sich gebildet ist, sein eigenes Leben hat, ... Jedes organische Wesen ist selbst eine Welt in sich. Alles Gesagte gilt von dem Organismus der Welt eben sowohl als von jedem einzelnen organischen Ganzen auf ihr ...91

Like Augustin, Gottfried Reinhold Treviranus, Carl Friedrich Burdach and Johann Michael Leupoldt all explain the 'organism' as a dynamic 'individual system' that repeats in itself, as a part of the 'general organism', the organic order of nature. ${ }^{92}$

87 For further references see G. Gusdorf, Le Romantisme, 3rd edn, Paris, 1993 (1st edn 2 vols., 1984), 143-70.

88 Goethe criticizes Oken for his ontological claims and romantic mysticism. Cf. S. Schmitt, 'Type et métamorphose dans la morphologie de Goethe, entre classicisme et romantisme', Revue d'histoire des sciences (2001), 54, 495-521.

89 J. W. von Goethe, 'Zur Morphologie', Volume 1 (1817), in idem, Johann Wolfgang von Goethe. Hamburger Ausgabe (ed. D. Kuhn and R. Wankmüller), 14 vols., 1988, München, 1988, xiii, 56 and 58. The passages are part of an introduction that is dated Jena 1807 ('Die Absicht eingeleitet'). Goethe's Die Metamorphose der Pflanzen was published in 1790.

90 C. G. Carus, 'Grundzüge der allgemeinen Naturbetrachtung (Einleitung zu den noch ungedrucktem Werke über die Ur-Theile des Schalen- und Knochengerüstes von D. C. G. Carus)', in J. W. Goethe, Zur Morphologie, Volume 2, Stuttgart and Tübingen, 1823, 84-95, 87. Carus later systematically employed the word 'organism' in Psyche. Zur Entwicklungsgeschichte der Seele, Pforzheim, 1846.

91 F. L. Augustin, Lehrbuch der Physiologie des Menschen mit vorzüglicher Rücksicht auf neuere Naturphilosophie und comparative Physiologie, Berlin, 1809, i, 65-6. Only one volume was published.

92 G. F. Treviranus, Biologie oder Philosophie der lebenden Natur für Naturforscher und Aerzte, 6 vols., Göttingen, 1802-22, i, 37, 68; C. F. Burdach, Die Physiologie, Leipzig, 1810, 67-72; and C. F. Leupoldt, Die 


\section{The individual 'organism' as a recurrent technical term}

In the 1790s the comparative anatomist Carl Friedrich Kielmeyer outlined a Naturlehre des Organismus and focused on the 'material individuality' (materielle Individualität) of the 'organism' as a specific form of Dasein and Organisation. ${ }^{93}$ Together with Lorenz Oken, Kielmeyer was one of the first naturalists to systematically use the term 'organism' as a generic name for individual entities. According to Kielmeyer, the naturalist who studies the 'physiology' of organic bodies has to search for the

Verschiedenheiten, die der Organismus - in der Veränderlichkeit betrachtet-und vorzüglich das Materiale an ihm in verschiedenen Zeiten von sich selbst zeigt, d.i. Veränderungen, die der Organismus erfährt, erleidet oder vornimmt während seines Daseins, und die sein Leben ausmachen. ${ }^{94}$

While Kielmeyer and Oken still discussed macrocosmic problems of order, Samuel Christian Lucae (1787-1821) referred in his Entwurf eines Systems der medicinischen Anthropologie (1816) only to the 'phenomena of life' (Lebenserscheinungen) and the order of individual 'organisms' that Kant defined as organized and organizing bodies in the Kritik der Urteilskraft (1790). ${ }^{95}$

However, it was only from around 1830 that the individual 'organism' became a recurrent technical term in various research fields. This transformation varied according to stylistic development and changes in those national languages which displaced Latin in academic and literary discourses from around 1750 on. ${ }^{96}$ Kielmeyer's French colleague Cuvier, working at the Muséum in Paris, did not use the word 'organism' in his major writings on anatomy. He probably avoided the metaphysical connotations that the word had acquired in its German context. ${ }^{97}$ Lamarck, who also worked in the

gesammte Anthropologie neu begründet durch allgemeine Biosophie und als zeitgemäße Grundlage der Medicin im Geiste germanisch-christlicher Wissenschaft, Erlangen, 1834, 56-7.

93 C. F. Kielmeyer, Gesammelte Schriften (ed. Fritz-Heinz Holler and J. Schuster), Berlin, 1938, 20 and 52-7. Kielmeyer (ibid., 111) also sketched an 'allgemeine Naturlebre des Lebens und des organismus'. For a detailed comparison between Schelling's and Kielmeyer's Naturlehre see T. Bach, Biologie and Philosophie bei C. F. Kielmeyer and F. W. J. Schelling, Stuttgart and Bad Cannstatt, 2001 (Schellingiana 12).

94 C. F. Kielmeyer, op. cit. (93), 21: 'differences, that the organism - examined in its variability -, and especially its very materiality, reveals of itself at different times, that is, changes that the organism undergoes, suffers or carries out during its existence, and which constitute its life'. This passage, written between 1790 and 1793, was part of Kielmeyer's plan to write a book on the anatomy and zoology of animals. See also ibid., 63-4 ('Über die Verhältnisse der organischen Kräfte untereinander in der Reihe der verschiedenen Organisationen, die Gesetze und Folgen dieser Verhältnisse', 1793).

95 Cf. S. C. Lucae, Entwurf eines Systems der medicinischen Anthropologie. Zum Gebrauche beim Studium der Natur- und Heilkunde des menschlichen Organismus. Erster Band. Geschichte des vegetativen Lebens im Individuum, Frankfurt am Main, 1816, 1: 'Den Inbegriff einer gewissen Anzahl zusammengesetzter, mit einander verknüpfter, gegenseitig auf einander wirkender, und durch ihr gemeinsames Wirken einander thätig und wirksam erhaltender Apparate, welche gerade durch ibre gegenseitige harmonische Zusammenstimmung einem allgemeinen großen Zweck, nämlich der Erhaltung des Ganzen, entgegenstreben, bezeichnet die Naturkunde durch die Bennung Organismus.' For his notion of phenomena of life see ibid., 26. 96 Cf. Kucharczik, op. cit. (4), 22.

97 Cuvier also did not use the word 'biology'. For Cuvier's notion of 'organisation' see T. Cheung, Die Organisation des Lebendigen. Die Entstehung des biologischen Organismusbegriffs bei Cuvier, Leibniz und Kant, Frankfurt am Main, 2000. 
Muséum, normally used the compound corps organisé. In the Système analytique des connaissances positives de l'homme (1820) he used the expression organisme distinct to describe an 'ensemble' of organs that is clearly visible to the naked eye, such as the digestive apparatus in the human body. ${ }^{98} \mathrm{He}$ distinguished it from an organisme indistinct as an ensemble of organs that is difficult to perceive, such as the nervous system. ${ }^{99}$ Both 'organisms' constitute 'organized bodies'. ${ }^{100}$

From around 1830 Ducrotay de Blainville, Johannes Müller, Richard Owen, Karl Ernst von Baer, Auguste Comte and Claude Bernard all frequently used the word 'organism' in physiology, embryology and milieu theories. ${ }^{101}$ In 1840 Justus Liebig also systematically employed the word in agrochemistry. ${ }^{102}$ Thus in the first three lectures of his Cours de physiologie générale et comparée (1829), at the Faculté des sciences in Paris, Blainville focused on a 'branch' of the new science biologie. He called this branch zoobiologie. Zoobiologists should analyse the phenomena of life 'in their relations to the [inner] organization or to outer circumstances'. ${ }^{103}$ The combination of inner and outer conditions characterizes the 'mode of life' of individual organismes:

La Zoobiologie, qui embrasse l'étude des divers actions intérieures des organismes, par suite de l'influence excercée sur eux par le monde extérieur, tant les actes de chaque organe, considérés isolément, que la liaison des actes de tous les organes, et leur réaction mutuelle, ce qui constitue la vie des animaux. ${ }^{104}$

98 In 1858 Rudolf Virchow still used the expression Organismus eines Knochens. See R. Virchow, Die Cellularpathologie in ihrer Begründung auf physiologische und pathologische Gewebelehre, Berlin, 1858,27 (second lecture).

99 J.-B. de Lamarck, Système analytique des connaissances positives de l'homme, Paris, 1988 (reprint; first published 1820), 163-6. An earlier reference is to be found in idem, Recherches sur l'organisation des corps vivants (1802) on the very helpful web page http://www.crhst.cnrs.fr/i-corpus/lamarck, based on a misspelling (organisme vitale instead of orgasme vitale). Cf. idem, Recherches sur l'organisation des corps vivants, Paris, 1986 (reprint; first published 1802), 57.

100 J.-B. de Lamarck, Système analytique, op. cit. (99), 163-6. In a similar way, Schiller distinguishes in his second medical dissertation (1780) between three 'organisms' (Organismus der Seelenwirkungen, Organismus der Ernährung and Organismus der Zeugung): 'Diese drei Organismi in den genauesten Lokalund Realzusammenhang gebracht, bilden den menschlichen Körper.' Cf. Friedrich Schiller, 'Versuch über den Zusammenhang der thierischen Natur des Menschen mit seiner Geistigen', in idem, Schillers Werke. Nationalausgabe (ed. B. von Wiese and H. Koppen), Weimar, 1943-, xx (1962), Part 1, 41-3.

101 Milne-Edwards did not use the word 'organism' in the Histoire naturelle des crustacés (1834-40) and the Elémens de zoologie (1834). He employed it only in the last section of the last (third) volume of the second edition of the Elémens (1843). Like the last chapter of the Histoire naturelle des crustacés, this section focuses on the geographic distribution of animals and their relation to specific environments or milieux. Cf. H. MilneEdwards, Elémens de zoologie ou leçons sur l'anatomie, la physiologie, la classification et les mours des animaux, 2nd edn, 3 vols., Paris, 1841-3, iii (1843), 338.

102 J. Liebig, Die organische Chemie in ihrer Anwendung auf Agricultur und Physiologie, Braunschweig, 1840.

103 D. de Blainville, Cours de physiologie générale et comparée, professé à la Faculté des Sciences de Paris, publié par les soins de M. le Docteur Hollard, 2 vols., Brussels, 1829, i, 18-19 (first lecture). A second edition in three volumes was published in 1833.

104 Blainville, op. cit. (103), i, 3-4 (first lecture). Blainville uses the word organisme in the singular and in the plural throughout the whole Cours de physiologie générale et comparée. Cf. ibid., i, 3, 4, 5, 7 (first lecture), and ii, 1, 2, 3, 4, 6 (thirteenth lecture). 
Johannes Müller, the German physiologist and anatomist who in 1833 became professor at the Friedrich-Wilhelm University in Berlin, frequently used the word Organismus, together with the expression organischer Körper, for individual living bodies in his Handbuch der Physiologie des Menschen (1833). ${ }^{105}$ In the second section of the prolegomena, with the title Vom Organismus und vom Leben, Müller defined the 'germ' as an 'unstructured' (formloses) 'potential whole' that develops into a Kantian whole-part unit. Müller called this unit an Organismus:

Die organischen Körper unterscheiden sich nicht bloß von den unorganischen durch die Art ibrer Zusammensetzung aus Elementen, sondern die beständige Thätigkeit, welche in der lebenden organischen Materie wirkt, schafft auch auch in den Gesetzen eines vernünftigen Plans mit Zweckmäßigkeit, indem die Theile zum Zwecke eines Ganzen angeordnet werden, und dies ist gerade, was den Organismus auszeichnet... Im Organismus ist also eine die Zusammensetzung aus ungleichen Gliedern beherrschende Einheit des Ganzen. ${ }^{106}$

Similarly, in the fifth of the extant Hunterian lectures on comparative anatomy and physiology at the Royal College of Surgeons in London, delivered on 11 May 1837, Richard Owen used the word 'organism' to characterize, as did Müller, a whole-part unit that grows out of a germ entity through an 'organizing energy' and 'vital stimuli'. ${ }^{107}$ Owen knew Müller's Handbuch and often paraphrased or directly translated from it. ${ }^{108}$ In the 1830s Karl Ernst von Baer, professor of natural history, comparative anatomy and physiology in Königsberg and St Petersburg (1822-52), focused on the 'developmental history' of individual animals. He criticized the idea of the recapitulation of 'forms' of lower animals or plants in the 'grades of development' of higher organic bodies. ${ }^{109}$ Baer rarely employed the word Organismus in the first volume of Über [die] Entwickelungsgeschichte der Thiere, published in $1827,{ }^{110}$ but he frequently used it in the second volume, published in $1837 .{ }^{111}$

Auguste Comte, who attended Blainville's lectures from 1829 to $1832,{ }^{112}$ outlined the concept of a new 'science of living bodies' in the third volume of the Cours de philosophie positive (1838). ${ }^{113} \mathrm{He}$ used the expressions organisme, organisme vivant or organisme unique (instead of the compounds 'living body' or 'organized being') when he discussed the life-constituting relation between organic bodies and the 'outer milieu'. ${ }^{114}$ Claude Bernard, successor of François Magendie in the chair of physiology at

105 J. Müller, Handbuch der Physiologie des Menschen, 2 vols., Koblenz, 1833-40, i, Prolegomena.

106 J. Müller, Handbuch der Physiologie des Menschen, 3rd edn, 1837, 19-20. Müller refers in the same passage to Kant's definition of organic unity.

107 R. Owen, The Hunterian Lectures in Comparative Anatomy. May-June, 1837 (ed. and with an introductory essay and commentary by P. R. Sloan), Chicago, 1992, 225, 230 (fifth lecture).

108 P. Sloan, in Owen, op. cit. (107), 15-39, 233-6.

109 K. v. Baer, Über Entwickelungsgeschichte der Thiere. Beobachtung und Reflexion, 2 vols., Königsberg, 1828-37, i, 221-2.

110 Baer, op. cit. (109), i, 200, 208.

111 Baer, op. cit. (109), ii, 3 (twice), 4, 8.

112 A. Comte, Cours de philosophie positive, 6 vols., Paris, 1830-42, iii (1838), 40th lesson, 269, note 1.

113 A. Comte, op. cit. (112), iii (1838), 40th lesson, 269. Comte uses also the expression science biologique. Cf. Comte, iii (1838), 277 and 284.

114 Comte, op. cit. (112), iii (1838), 289, 290, 291, 292, 302, 303, 304, 308 and 310. 
the Collège de France in $1855^{115}$ and a student of Milne-Edwards, frequently employed the word organisme in his Introduction à l'étude de la médecine expérimentale (1865) after the first part on methodology. ${ }^{116}$ Before the Introduction, Bernard had already used the term 'organism' in Leçons de physiologie expérimentale appliquée à la médecine (1855-6), in which he described for the first time the glycogen synthesis (glycogenèse) of the liver. ${ }^{117}$ Bernard argued against Comte that regulating processes of the inner milieu are more important than outer circumstances.

After Blainville, Comte and Bernard, French dictionaries systematically replaced expressions such as 'organic body' or organic 'organization' with the word 'organism'. The first appearance of the word 'organism' in a French dictionary can be found in the Dictionnaire de Trévoux of $1771 .{ }^{118}$ The author of the article defined the organisme as the 'quality to be organized' and quoted Bourguet's Lettres philosophiques. However, in many French dictionaries on natural history in the first half of the nineteenth century, the word organisme does not occur. ${ }^{119}$ If the word is listed, the author normally refers to its abstract meaning as a principle of order and as a synonym for the word organisation. ${ }^{120}$ The word finally appeared in 1865 in the twelfth edition of Littré and Robin's Dictionnaire de médecine ${ }^{121}$ and in 1878 in the seventh edition of the

115 Bernard already represented Magendie at the Collège from 1848.

116 C. Bernard, Introduction à l'étude de la médecine expérimentale, Brussels, 1965 (reprint; first published Paris, 1865), 102, 106, 107, 108.

117 C. Bernard, Leçons de physiologie expérimentale appliquée à la médecine, 2 vols., Paris, 1855-6, i, 9-10, and ii, 1-2. In On the Origin of Species, published shortly after Bernard's Leçons in 1859, Darwin employed the word 'organism' in the first four chapters, in which he focuses on the importance of the 'relation of organism to organism', and, more frequently, in the chapters on the geological record and the geographical distribution of species. He normally uses the expressions 'organic being' and 'individual'. See C. Darwin, On the Origin of Species, Cambridge, MA and London, 1964 (facsimile of London, 1859 edn), 9 (Chapter 1), 50 (Chapter 2), 60 and 65 (Chapter 3), 103-4 (Chapter 4) and Chapters 9-12. The term does not occur in Chapters 5-8.

118 The full title is Dictionnaire universel françois et latin, vulgairement appelé dictionnaire de Trévoux. Contenant la Signification \& la Définition des mots de l'une \&o de l'autre Langue; avec leurs différens usages; les termes propres de chaque Etat \& de chaque Profession: La Description de toutes les choses naturelles 6 artificielles, leurs espèces, leurs propriétés: L'Explication de tout ce que renferment les Sciences \& les Arts, soit Libéraux, soit Méchaniques, \&'c. Nouvelle Édition. Corrigée et considérablement augmentée, 6th edn, 8 vols., Paris, 1771, vi, 389: 'Organisme. S. m. Qui appartient à l'organisation des corps, la qualité d'être organisé. Tout est organique dans la nature, le règne minéral, autant que le végétal \& l’animal, quoique dans un ordre différent de ce que les Philosophes \& les Chimistes ont imaginé. Cet organisme consiste d'abord en des corpuscules d'une petitesse infinie, dont les figures sont géométriques, mais des plus simples. BOURGUET, Lettr. Phil.'

119 Dictionnaire des sciences naturelles ... (ed. F.-G. Levrault et al.), 60 vols. (without supplements and engravings), Paris and Strasbourg, 1804-30, xxxvi (1825); and Dictionnaire universel d'histoire naturelle (ed. C. D’Orbigny et al.), 13 vols., Paris, 1841-9, ix (1847).

120 Dictionnaire pittoresque d'Histoire naturelle et des phénomènes de la Nature (ed. F.-E. Guèrin), 9 vols., Paris, 1833-9, vi, 408: 'Organisme: le mot, pour la plupart des physiologistes modernes, est un synonyme d'organisation; il sert plus spécialement à désigner l'ensemble des lois qui régissent les êtres organisés, animaux ou végétaux.' The article is attributed to Paul Gentil.

121 Littré and Robin distinguished between 'simple or composed organisms' (as humans, oak trees, horses, eggs or seeds), that can exist as individual entities, and 'organized bodies' that represent 'anatomical parts' (for example muscle fibres or cells) of 'organisms'. See Dictionnaire de médecine, de chirurgie, de pharmacie, des sciences accessoires, de l'art vétérinaire et des sciences qui s'y rapportent (ed. E. Littré and Ch. Robin), 12th edn, Paris, 1865, 1056. 
Dictionnaire de l'Académie française as an 'ensemble of organs that execute the functions of life'. ${ }^{122}$

\section{Conclusion}

After its occurrence in two medieval sources, the usage of the word 'organism' in the seventeenth century is well documented for Stahl (1684) in Latin and for Leibniz (1687) in French. Around 1700 the word occurs in English (Grew 1701, Evelyn 1706), Italian (Minerva di Gallica 1708, Vallisnieri 1729) and later also in German (Zedler 1740). Stahl used the word Organismus to refer to a general principle of order in animated bodies which is different from a Mechanismus. For Leibniz the 'organism' represents a principle of order according to a divine mechanism and its metaphysical foundations. Stahl thought that the soul directly informs the movements of the animated body, while Leibniz introduced the notion of a pre-established harmony between body and soul. For Grew the organism mediates as a mechanic order between the expressions of the soul or a vital force and its body.

Throughout the eighteenth century and during the early decades of the nineteenth, French natural historians as well as anatomists and physiologists normally referred to compounds such as 'organic body' or 'organized body'. The Wolffian school of the first half of the eighteenth century only distinguished between the ontology of being and the physiology of 'organic bodies' as mechanic aggregates. In the final decades of the eighteenth century the dialectics between the microcosm of living entities and the macrocosm of nature together with the transformation of theories of the unconditioned self into models of processual self-differentiation became characteristic of the occurrence of the word 'organism' as a generic name for individual entities in the German philosophical context (Kant, Herder, Schelling, Hegel). At the turn of the eighteenth century and in the first decades of the nineteenth, the expression 'individual organism' also appeared in Naturphilosophien (Oken, Goethe, Carus) and in physiological anthropologies (Treviranus, Augustin, Burdach, Leupoldt). Naturphilosophien and anthropologies were of course closely related to the micro-macrocosm problem and to the notion of 'organism' as a particular organic system within the general organic order of nature. Finally, from around 1830 the word 'organism' became a recurrent technical term within various research fields such as anatomy, physiology, embryology and milieu theories. Within these fields 'organisms' were defined as whole-part units (Müller, Owen) and natural entities determined by outer and inner milieux (Blainville, Comte, Bernard). 